\title{
Occurrence of Intracellular Inclusions and Plasmids in Xenorhabdus spp.
}

\author{
By G. A. COUCHE, P. R. LEHRBACH, R. G. FORAGE, G. C. COONEY, \\ D. R. SMITH AND R. P. GREGSON* \\ Biotechnology Australia Pty Ltd, PO Box 20, Roseville, NSW 2069, Australia
}

(Received 19 August 1986)

\begin{abstract}
Entomopathogenic bacteria of the genus Xenorhabdus produce crystalline inclusion bodies during in vitro culture. When cultured in liquid media, inclusions were present in primary forms but not secondary forms of $X$. nematophilus. In contrast, both primary and secondary forms of $X$. luminescens produced inclusion bodies during liquid culture. Two morphologically distinct forms of inclusion bodies were found in $X$. nematophilus subsp. nematophilus strain All. They were proteinaceous, and one of the proteins (IP-1) was present in seven strains of $X$. nematophilus subsp. nematophilus, but not in strains of $X$. nematophilus subsp. bovienii, $X$. nematophilus subsp. poinarii, $X$. nematophilus subsp. beddingii or $X$. luminescens. This protein may be useful as a taxonomic indicator. Plasmids were isolated from seven of ten strains of Xenorhabdus. They varied in size from 12 to $3.6 \mathrm{~kb}$, and were present in both primary and secondary forms of $X$. nematophilus subsp. nematophilus and $X$. nematophilus subsp. bovienii.
\end{abstract}

\section{INTRODUCTION}

Insect pathogenic nematodes of the families Heterorhabditidae and Steinernematidae are symbiotically associated with bacteria of the genus Xenorhabdus (Thomas \& Poinar, 1979; Akhurst, 1980). The bacterial symbiont is carried monoxenically within the intestine of nonfeeding, infective-stage nematodes. Following invasion of an insect host, the infective nematode releases the bacteria, which contribute to killing the insect and enhance conditions for the reproduction of nematodes (Poinar \& Thomas, 1966). Xenorhabdus species occur in two morphological forms (designated primary and secondary) which can be distinguished as differently coloured colonies on various bacteriological media and/or on the basis of antibiotic production (Akhurst, 1980, 1982). Both forms are pathogenic to insect larvae, but only the primary form is isolated from infective nematodes (Akhurst, 1980). Ultrastructural studies of various Xenorhabdus species have identified crystalline inclusions similar in appearance to the crystals of Bacillus thuringiensis (Boemare et al., 1983; Grimont et al., 1984).

Our investigations leading to the commercial development of entomogenous nematodes for use as insecticides have included studies on several aspects of the biology of Xenorhabdus bacteria. During investigations with $X$. nematophilus subsp. nematophilus (strain All), inclusions were observed in cells from primary form cultures. Two types of proteinaceous inclusion were isolated, large cigar-shaped inclusions containing a $26 \mathrm{kDa}$ protein (IP-1) and small ovoid inclusions containing a $22 \mathrm{kDa}$ protein (IP-2). The physico-chemical properties of these proteins and the kinetics of their synthesis will be described elsewhere (unpublished). In this report we describe the use of microscopic, electrophoretic and immunological techniques to examine a number of Xenorhabdus strains for inclusion formation during in vitro culture. Plasmid DNA profiles from these strains were prepared to examine the possible involvement of plasmid encoded functions in the formation of inclusion bodies and the transition from primary to secondary form.

Abbreviation: PMSF, phenylmethylsulphonyl fluoride. 
Table 1. Xenorhabdus strains and their host nematodes

\begin{tabular}{|c|c|c|c|c|}
\hline \multicolumn{2}{|c|}{ Bacterium } & \multicolumn{2}{|c|}{ Nematode } & \multirow[b]{2}{*}{ Origin } \\
\hline Species & Strain & Species & Strain & \\
\hline \multirow{7}{*}{$\begin{array}{l}X . \text { nematophilus } \\
\text { subsp. nematophilus }\end{array}$} & All & Steinernema feltiae & All & Georgia, USA \\
\hline & Mex & & Mexican & Chihuahua, Mexico \\
\hline & AN6 & & DD136 & Virginia, USA \\
\hline & BK & & Breton & Brittany, France \\
\hline & A24 & & Agriotos & Leningrad, USSR \\
\hline & $\mathrm{XnT}$ & & DD136 & Virginia, USA \\
\hline & $\mathrm{Pi}$ & & Pieridarum & Poland \\
\hline \multirow{3}{*}{$\begin{array}{l}X . \text { nematophilus } \\
\text { subsp. bovienii }\end{array}$} & T319 & S. bibionis & T319 & Tasmania, Australia \\
\hline & SK2 & S. kraussei & $\mathrm{SK} / 2$ & Czechoslovakia \\
\hline & Dan 5 & S: affinis & Dan 5 & Denmark \\
\hline $\begin{array}{l}X . \text { nematophilus } \\
\text { subsp. poinarii }\end{array}$ & NC513 & S. glaseri & $\mathrm{NC} 513$ & N Carolina, USA \\
\hline $\begin{array}{l}X . \text { nematophilus } \\
\text { subsp. beddingii }\end{array}$ & Q385 & Steinernema sp. & Q385 & Queensland, Australia \\
\hline \multirow[t]{2}{*}{$X$. luminescens } & B1 & Heterorhabditis & - & South Australia, Australia \\
\hline & T327 & Heterorhabditis sp. & - & Tasmania, Australia \\
\hline
\end{tabular}

METHODS

Bacterial strains. The strains of Xenorhabdus used in this study are listed in Table 1. All strains were kindly provided by Drs R. Bedding and R. Akhurst, CSIRO, Division of Entomology, Tasmania, Australia.

Media and culture conditions. Xenorhabdus strains were cultured and maintained on nutrient agar supplemented with $0.004 \%$ triphenyl tetrazolium chloride and $0.025 \%$ bromothymol blue (NBT agar; Akhurst, 1980). Where appropriate, NBT agar was used to distinguish primary and secondary forms as previously described (Akhurst, 1980; Hotchin \& Kaya, 1984). However, primary and secondary forms of some strains (SK2, NC513, B1, T327) could not be distinguished on the basis of colony colour on NBT agar. Primary forms of these strains produce antibiotics, which were detected using overlay procedures with Micrococcus luteus as the test organism (Akhurst, 1982). Tryptone soya broth (Oxoid) was used as the complete growth medium for liquid cultures. Bacteria were cultured at $28^{\circ} \mathrm{C}$ in $500 \mathrm{ml}$ Erlenmeyer flasks containing $100 \mathrm{ml}$ medium aerated by rotary agitation on an orbital shaker operating at 160 r.p.m.

Isolation of inclusions from $X$. nematophilus subsp. nematophilus (All). The bacteria were grown to stationary phase $(48 \mathrm{~h})$, harvested by centrifugation, resuspended in buffered saline $\left(15 \mathrm{~mm}-\mathrm{K}_{2} \mathrm{HPO}_{4}, 85 \mathrm{mM}-\mathrm{NaCl}, \mathrm{pH} \mathrm{7 \cdot 3}\right)$, and disrupted by passage through a French press at $14000 \mathrm{lbf}^{-2}(96.6 \mathrm{MPa})$. Inclusions were purified from the lysate by differential centrifugation $(450 \mathrm{~g}, 5 \mathrm{~min})$ in $30 \%(\mathrm{w} / \mathrm{w})$ glycerol, followed by centrifugation $(1500 \mathrm{~g}, 15$ $\mathrm{min}$ ) in discontinuous gradients formed by successive layering of $10 \mathrm{ml} 75,60$ and $30 \%$ (w/w) glycerol. The inclusions banding in the $60 \%$ glycerol layer and at the $60 / 75 \%$ glycerol interface were further purified by isopycnic density gradient centrifugation $(20000 \mathrm{~g}, 60 \mathrm{~min}$ ) in linear $40-55 \%(\mathrm{w} / \mathrm{v})$ sodium diatrizoate (Sigma) gradients. Inclusion bands were washed free of residual salt and lyophilized.

Preparation of cell lysates and protein estimation. Cells from $1 \mathrm{ml}$ stationary-phase broth culture were suspended in $3 \mathrm{ml}$ buffered saline containing $0.5 \mathrm{~mm}$-PMSF and $5 \mathrm{~mm}$-EDTA, then lysed by passage through a French press at $14000 \mathrm{lbf} \mathrm{in}^{-2}$. Portions of lysate were solubilized in $2 \%(\mathrm{w} / \mathrm{v})$ SDS for $30 \mathrm{~min}$ at room temperature, and total protein was estimated as described below from dot blots prepared using a Minifold microfiltration apparatus (Schleicher and Schuell). SDS-solubilized proteins were diluted to $250 \mu \mathrm{l}$ with deionized $\mathrm{H}_{2} \mathrm{O}$ and the proteins were precipitated by the addition of $50 \mu \mathrm{l} \mathrm{90 \% (w/v)} \mathrm{TCA.} \mathrm{Protein} \mathrm{precipitates} \mathrm{were} \mathrm{collected} \mathrm{on} \mathrm{nitrocellulose,}$ washed with $6 \%(\mathrm{w} / \mathrm{v})$ TCA, stained for $10 \mathrm{~min}$ with $0.25 \%(\mathrm{w} / \mathrm{v})$ naphthol blue black in $50 \%(\mathrm{v} / \mathrm{v}) \mathrm{methanol}, 10 \%$ $(\mathrm{v} / \mathrm{v})$ acetic acid, and destained in $90 \%(\mathrm{v} / \mathrm{v})$ methanol, $2.0 \%(\mathrm{v} / \mathrm{v})$ acetic acid. Protein spots were excised, the dye was eluted in $1 \mathrm{ml} 25 \mathrm{~mm}-\mathrm{NaOH}, 50 \mathrm{~mm}-\mathrm{EDTA}$ in $50 \%(\mathrm{v} / \mathrm{v})$ ethanol, and the $A_{630}$ was determined. Protein content was estimated by comparison with IP-1 protein standards.

$S D S-P A G E$ of cell lysates. Portions of lysate containing $100 \mu \mathrm{g}$ total protein were solubilized in $2 \%(\mathrm{w} / \mathrm{v})$ SDS and precipitated with TCA as described above. Precipitates were harvested by centrifugation (Beckman Microfuge), washed twice with $1 \mathrm{ml} \mathrm{100 \%}$ ethanol, and resuspended in $50 \mu$ I SDS sample buffer. Samples were heated to $100{ }^{\circ} \mathrm{C}$ for $5 \mathrm{~min}$ and insoluble material was removed by centrifugation. Samples were analysed in $12.5 \%$ 
(w/v) gels as described by Laemmli (1970). Electrophoresis was done in a Bio-Rad Miniprotean II electrophoresis cell following the manufacturer's instructions. Gels were stained with Coomassie blue R-250 or subjected to electrophoretic transfer blotting onto nitrocellulose.

Preparation of antisera. Purified inclusions were solubilized in SDS sample buffer and subjected to electrophoresis in $3 \mathrm{~mm}$ thick preparative SDS gels. Following electrophoresis, gels were incubated at $4{ }^{\circ} \mathrm{C}$ in $0.25 \mathrm{M}-\mathrm{K} \mathrm{Cl}$ for $30 \mathrm{~min}$. White bands corresponding to precipitated potassium dodecyl sulphate-protein complexes were excised, divided into three equal portions and stored at $-20^{\circ} \mathrm{C}$. Gel strips containing approximately $200 \mu \mathrm{g}$ protein were thawed, macerated with a spatula, mixed with $1 \mathrm{ml} 0.85 \%$ saline and $1.5 \mathrm{ml}$ Montanide 888 adjuvant [Montanide 888 (SEPPIC) diluted 1 vol. in 9 vols Marcol 52 oil], and then homogenized using a Sorvall Omnimixer. The resulting emulsion was injected into New Zealand White rabbits in a series of three injections, $1 \mathrm{ml}$ intramuscularly into each hip and $1 \mathrm{ml}$ subcutaneously in the neck. Rabbits received a similar series of injections at monthly intervals for three months, and were bled $3 \mathrm{~d}$ after the final challenge. Crude serum was affinity purified on Protein A-Sepharose (Pharmacia) equilibrated with PBS (0.1 M- $\mathrm{Na}_{2} \mathrm{HPO}_{4} 0 \cdot 17 \mathrm{M}-\mathrm{NaCl}, \mathrm{pH} \mathrm{8.0)}$. Bound IgG was eluted with $0 \cdot 1 \mathrm{M}$-glycine $/ \mathrm{HCl}, \mathrm{pH} 3 \cdot 0$. Fractions $(4 \mathrm{ml})$ containing IgG were immediately mixed with $2 \mathrm{ml} 2 \mathrm{M}$-Tris/ $\mathrm{HCl}, \mathrm{pH} \mathrm{8.0,} \mathrm{and} \mathrm{then} \mathrm{pooled.} \mathrm{The} \mathrm{resulting} \mathrm{solution} \mathrm{was} \mathrm{extensively} \mathrm{dialysed} \mathrm{against} 0 \cdot 1 \mathrm{M}-$ $\mathrm{NaCl}$ at $4^{\circ} \mathrm{C}$. The final IgG concentration was adjusted to $1 \mathrm{mg} \mathrm{ml}^{-1}$ with $0 \cdot 1 \mathrm{M}-\mathrm{NaCl}$, and the solution was divided into $1 \mathrm{ml}$ portions and stored at $-20^{\circ} \mathrm{C}$.

Analysis of proteins by electrophoretic transfer blotting. Proteins from acrylamide gels were electrophoretically transferred to nitrocellulose (Towbin, 1979; Burnette, 1981) in a Hoefer Mighty Small Transphor unit. Nonspecific binding sites on nitrocellulose filters were blocked by a 90 min incubation in Blotto, a solution of $10 \%$ $(\mathrm{w} / \mathrm{v})$ milk powder in $10 \mathrm{~mm}$-Tris, $0.15 \mathrm{M}-\mathrm{NaCl}$, pH 7.5 (Johnson et al., 1984). The filters were rinsed twice in Tris/saline/Tween ( $1 \mathrm{~min}$ each; $12 \mathrm{~mm}-\mathrm{Tris}, 0.12 \mathrm{M}-\mathrm{NaCl}, 0.05 \%$, v/v, Tween $20, \mathrm{pH} 8.0$ ) and then incubated overnight at $4{ }^{\circ} \mathrm{C}$ in a $1: 1$ mixture of anti-IP-1 and anti-IP-2 IgG, final IgG concentration $1 \mu \mathrm{gl}^{-1}$ in Tris/saline/Tween. Filters were successively washed three times each in Tris/saline ( $12 \mathrm{~mm}-\mathrm{Tris}, 0 \cdot 12 \mathrm{M}-\mathrm{NaCl}$, pH 8.0), Tris/saline/Tween, and Tris/saline. Anti-rabbit IgG-alkaline phosphatase conjugate (Sigma) diluted 1/5000 with Tris/saline/Tween was added and the reaction was allowed to proceed at room temperature for $90 \mathrm{~min}$. Unbound conjugate was removed by washing as described above. Bound IgG was revealed by addition of a substrate solution containing $0.01 \%(\mathrm{w} / \mathrm{v})$ nitro-blue tetrazolium, $50 \mu \mathrm{g} \mathrm{ml} \mathrm{m}^{-1}$ 5-bromo-4-chloro-3-indoxyl phosphate and $3 \mathrm{mM}-\mathrm{MgCl}_{2}$ in $0 \cdot 18 \mathrm{M}$-sodium barbitone/sodium acetate, $\mathrm{pH} 10 \cdot 0$.

Analysis of plasmid DNA. Plasmid DNA was isolated from cells by alkaline lysis as described by Maniatis et al. (1982). Procedures for the analysis of DNA by restriction endonucleases (EcoRI and BamHI) and agarose gel electrophoresis were as reported previously (Lehrbach et al., 1983).

\section{RESULTS}

\section{Occurrence of inclusions}

When Xenorhabdus was cultured on NBT agar for $72 \mathrm{~h}$, inclusions were present in all isolates with the exception of secondary form $X$. nematophilus subsp. nematophilus strain All (Table 2). In shake flasks, cultures reached stationary phase in $48 \mathrm{~h}$ at $28^{\circ} \mathrm{C}$. At this time, inclusions were visible in cells from primary-form cultures of most strains, and in secondary forms of $X$. luminescens (B1 and T327). Neither primary- nor secondary-form cultures of $X$. nematophilus subsp. poinarii (strain NC513) contained inclusion-forming cells.

Inclusion morphology varied with the strain of Xenorhabdus. Small ovoid inclusions were present in all inclusion-forming strains, and were the only type of inclusion produced by strains SK2, Q385 and B1. Strains All, BK, A24, AN6, Mex, T319, Dan 5 and T327 produced inclusions of variable morphology and size, and commonly contained more than one inclusion (Fig. 1). The frequency of occurrence of inclusion-containing cells in TSB cultures was similarly variable. In cultures of strains All, BK, A24, Mex, AN6, T319 and T327, over $50 \%$ of cells contained one or more inclusions.

\section{Electrophoretic analysis of cell lysates from Xenorhabdus strains}

Cell lysates of $48 \mathrm{~h}$ cultures were analysed by SDS-PAGE to determine whether IP-1 and IP-2 were common to all strains of Xenorhabdus (Fig. 2). Bands appearing to correspond to IP-1 were present in extracts from primary-form cultures of $X$. nematophilus subsp. nematophilus (strains All, Mex and AN6; Fig. $2 a$, lanes 3, 4 and 5), while a band of similar mobility to IP-2 was found in extracts of strains All and Mex (Fig. $2 a$, lanes 3 and 4). IP-1 and IP-2 did not appear to be present in lysates of primary- or secondary-form $X$. nematophilus subsp. bovienii (T319, SK2 


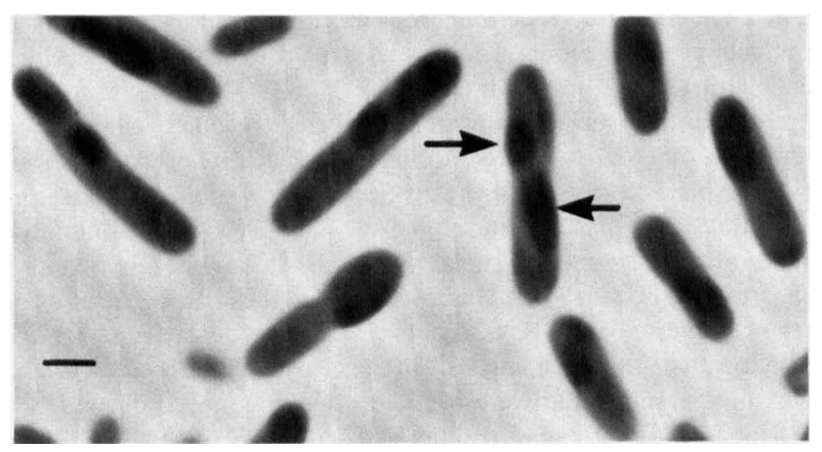

Fig. 1. Cells of $X$. nematophilus subsp. nematophilus, strain Mex. Dense inclusion bodies of variable morphology are present (arrows). Bar, $1 \mu \mathrm{m}$.

Table 2. Occurrence of inclusions and plasmids in selected strains of Xenorhabdus

\begin{tabular}{|c|c|c|c|c|c|}
\hline \multirow[b]{2}{*}{ Strain } & \multirow[b]{2}{*}{ Form* } & \multicolumn{2}{|c|}{$\begin{array}{l}\text { Presence of } \\
\text { inclusions } \dagger\end{array}$} & \multirow{2}{*}{$\begin{array}{c}\text { Inclusion } \\
\text { morphology } \ddagger\end{array}$} & \multirow[b]{2}{*}{$\begin{array}{l}\text { Plasmid } \\
\text { size }(k b) \S\end{array}$} \\
\hline & & NBT agar & TSB & & \\
\hline \multirow[t]{2}{*}{ All } & $1^{\circ}$ & + & + & V & $12,3 \cdot 6$ \\
\hline & $2^{\circ}$ & - & - & - & $12,3 \cdot 6$ \\
\hline \multirow[t]{2}{*}{ BK } & $1^{\circ}$ & + & + & V & $12,3 \cdot 6$ \\
\hline & $2^{\circ}$ & + & + & - & $12,3 \cdot 6$ \\
\hline \multirow[t]{2}{*}{ A24 } & $1^{\circ}$ & + & + & V & $12,3 \cdot 6$ \\
\hline & $2^{\circ}$ & + & - & - & $12,3 \cdot 6$ \\
\hline \multirow[t]{2}{*}{$\mathrm{XnT}$} & $1^{\circ}$ & ND & ND & ND & 10 \\
\hline & $2^{\circ}$ & ND & ND & ND & 10 \\
\hline Mex & $1^{\circ}$ & + & + & V & 7 \\
\hline AN6 & $1^{\circ}$ & + & + & v & - \\
\hline T319 & $1^{\circ}$ & + & + & V & $7,3.6$ \\
\hline SK2 & $1^{\circ}$ & + & + & 0 & $5,3.6$ \\
\hline \multirow[t]{2}{*}{ Dan 5} & $1^{\circ}$ & + & + & V & - \\
\hline & $2^{\circ}$ & + & - & - & - \\
\hline \multirow[t]{2}{*}{ NC513 } & $1^{\circ}$ & + & - & - & ND \\
\hline & $2^{\circ}$ & + & - & - & ND \\
\hline \multirow[t]{2}{*}{ Q385 } & $1^{\circ}$ & + & + & o & - \\
\hline & $2^{\circ}$ & + & - & - & - \\
\hline Bl & $2^{\circ}$ & + & + & O & ND \\
\hline T327 & $2^{\circ}$ & + & + & V & ND \\
\hline
\end{tabular}

ND, Not determined.

- Primary $\left(1^{\circ}\right)$ and secondary $\left(2^{\circ}\right)$ forms determined from colony pigmentation on NBT agar indicator plates, or from the presence of antibiotics as revealed by Micrococcus overlay procedures.

† NBT agar, nutrient agar containing bromothymol blue and triphenyl tetrazolium chloride; TSB, tryptone soya broth. + , Inclusions present; - , inclusions absent.

$\ddagger$ Morphology of inclusions in TSB cultures: O, ovoid; V, variable.

$\S$ Plasmid DNA size was determined by agarose gel electrophoresis of fragments obtained by cleavage with restriction endonucleases EcoRI and BamHI and comparison with known DNA size markers. -, No plasmids detected.

and Dan 5), X. nematophilus subsp. poinarii (NC513), X. nematophilus subsp. beddingii (Q385), or $X$. luminescens (B1 and T327).

\section{Analysis of cell lysates by electrophoretic transfer blotting}

Immunological detection was used to identify IP-1 and IP-2 or other forms of these proteins in cell lysates (Fig. 3). Immunoblots confirmed the presence of IP-1 in lysates of $X$. nematophilus subsp. nematophilus strains All, Mex and AN6, and its absence in lysates from primary or 
(a)

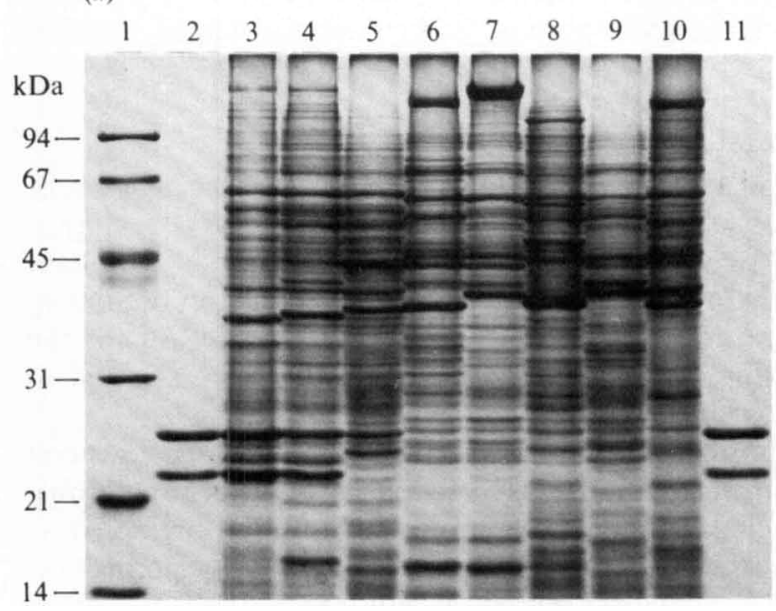

(b)

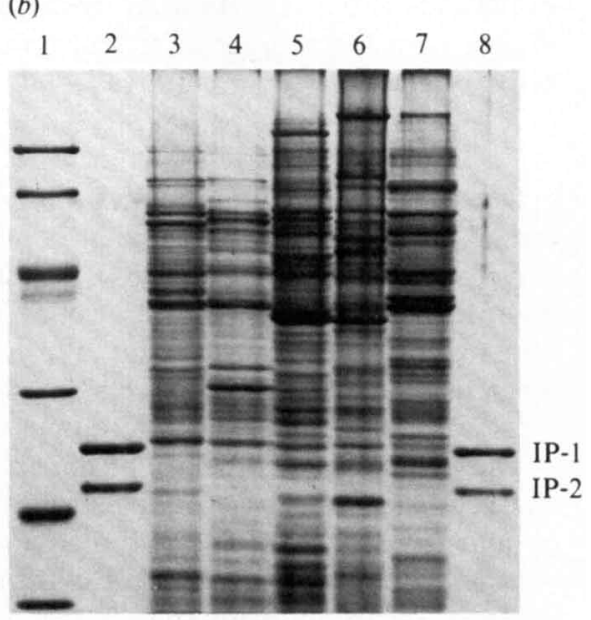

Fig. 2. SDS-PAGE of Xenorhabdus lysates. (a) Primary form: lane 1, molecular mass marker proteins (Bio-Rad); lanes 2 and 11, purified IP-1 and IP-2 (0.5 $\mu$ g per band); lanes 3-10, strains All, Mex, AN6, SK2, T319, NC513, Dan 5 and Q385 respectively. (b) Secondary form: lane 1, molecular mass marker proteins; lanes 2 and 8, purified IP-1 and IP-2 (0.5 $\mathrm{g}$ per band); lanes 3-7, strains T327, B1, NC513, Q385 and Dan5 respectively. Lysate samples contained approximately $8 \mu \mathrm{g}$ protein.

(a)

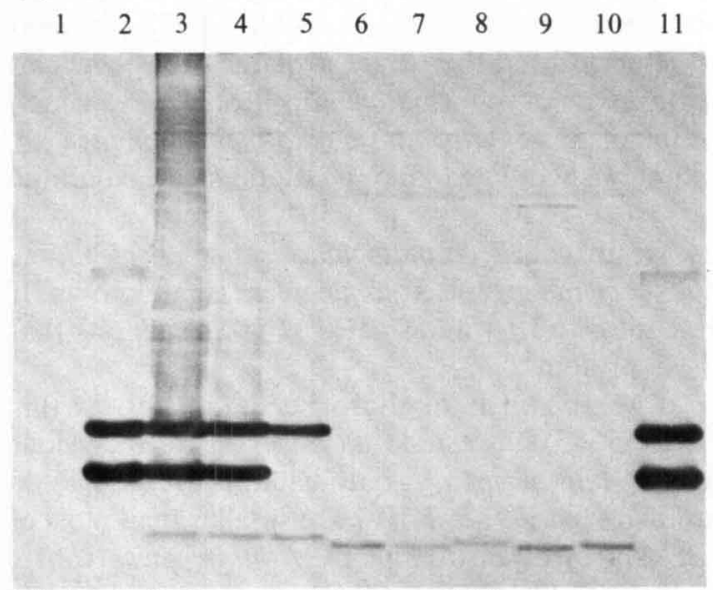

(b)

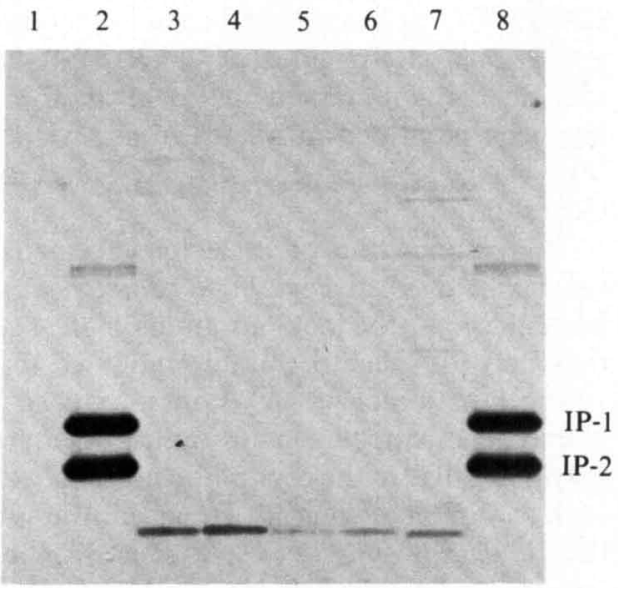

Fig. 3. Immunoblots from SDS-PAGE gels of $(a)$ primary form and $(b)$ secondary form Xenorhabdus lysates. Molecular mass markers, inclusion protein standards, and strains are as described in Fig. 2 . The lysate samples for SDS-PAGE contained approximately $4 \mu \mathrm{g}$ protein; the inclusion protein standards contained $0.25 \mu \mathrm{g}$ per band.

secondary cultures of ten other Xenorhabdus strains. Similarly, IP-2 was found in cultures of $X$. nematophilus subsp. nematophilus All and Mex, but was absent from the others. The antiinclusion protein $\mathrm{IgG}$ further recognized a minor band of approximately $18 \mathrm{kDa}$ in all lysates, and background reaction with higher molecular mass proteins was significant in samples from those strains that synthesized large quantities of IP-1 and IP-2 (Fig. 3a, lanes 3 and 4).

\section{Presence of plasmids in Xenorhabdus strains}

The presence of plasmid DNA in ten strains of Xenorhabdus was determined using agarose gel electrophoresis. Plasmids were detected in primary-form cultures of seven of the ten strains 
examined (Table 2), with three of these (All, BK and A24) having identical plasmid patterns. Where both forms were analysed, no differences in plasmid content were detected between primary and secondary cultures.

\section{DISCUSSION}

Ultrastructural studies of cells from various Xenorhabdus strains have revealed the presence of crystalline inclusion bodies similar in morphology to the crystals of $B$. thuringiensis (Boemare $e t$ al., 1983; Grimont et al., 1984). These inclusions can be readily observed under the light microscope using phase contrast optics, where they appear as phase bright structures occupying up to a third of the cytoplasm. We have examined various strains of Xenorhabdus for the formation of intracellular inclusions during in vitro culture. These strains were selected to represent the major taxonomic groups described by Akhurst (1983, 1986).

The ability to form inclusions under appropriate culture conditions appears to be a general characteristic of Xenorhabdus bacteria, as inclusions were observed in most of the cultures grown on nutrient agar. In rich liquid media such as tryptone soya broth, inclusion formation by $X$. nematophilus strains is dependent on the morphological and presumably physiological form of the bacteria. Inclusions were present only in primary-form cultures except for strain NC513 where neither primary nor secondary forms produced inclusions. In contrast, both primary forms (Boemare et al., 1983) and secondary forms of $X$. luminescens produced inclusions in liquid media.

Two morphologically distinct types of inclusion were formed in primary cultures of $X$. nematophilus subsp. nematophilus, strain All. SDS-PAGE analysis of purified inclusions from these bacteria has revealed that both types of inclusion are proteinaceous, and that each is composed of a single protein subunit (IP-1 or IP-2). Electrophoretic blotting of proteins from SDS-PAGE gels onto nitrocellulose, followed by immunological detection with polyclonal antisera prepared against IP-1 and IP-2, has demonstrated that these proteins are subspecies specific, being found only in lysates of $X$. nematophilus subsp. nematophilus. Protein IP-1 which has been identified in lysates from seven strains of $X$. nematophilus subsp. nematophilus (All, Mex, AN6, Fig. $3 a$; BK, A24, XnT and Pi, unpublished data), may be useful as a taxonomic indicator.

The composition of inclusions formed by strains of $X$. nematophilus subsp. bovienii, $X$. nematophilus subsp. poinarii, $X$. nematophilus subsp. beddingii and $X$. luminescens is not known. If proteinaceous, the lack of immunological relatedness to IP-1 and/or IP-2 (Fig. 3) suggests that they may also be structurally unrelated to these proteins.

The function(s) of inclusions produced by Xenorhabdus is likely to be significant, as this phenomenon appears in all strains. Boemare et al. (1983) suggested that Xenorhabdus inclusions may be similar to the crystalline protein toxins of $B$. thuringiensis, as both bacteria are associated with entomopathogenesis. However, the subunit sizes of IP-1 and IP-2 are smaller than most of the $B$. thuringiensis toxins, except for the $28 \mathrm{kDa}$ cytolytic toxin of $B$. thuringiensis subsp. israelensis (Davidson \& Yamamoto, 1984; Hurley et al., 1985). Furthermore, no toxicity was detected when IP-1 and/or IP-2 were administered by injection or feeding to insects such as Heliothis punctiger and Lucilia cuprina. Haemolytic activity such as that associated with the $28 \mathrm{kDa}$ protein of the $B$. thuringiensis subsp. israelensis crystal (Thomas \& Ellar, 1983; Pfannenstiel et al., 1984) has not been detected in solubilized IP-1 and/or IP-2 preparations. The role(s) of inclusion proteins is therefore unclear. The possibility that these proteins serve as a nutrient and/or energy source while the host nematode is dormant in the soil is being investigated further.

Plasmids have not previously been detected in Xenorhabdus strains (Akhurst, 1980); however we have identified one or more plasmids in many of the strains examined. Plasmid content was similar in primary-and secondary-form cultures, suggesting that plasmid loss is not involved in the transition from primary to secondary form. The question of whether plasmid-encoded functions are involved in inclusion body formation requires further investigation. This is apparently not so in certain strains (AN6, Dan 5 and Q385), as these strains form inclusions but lack plasmids. 
The authors wish to acknowledge the contributions of Dennis R. Thiele, Rodney H. Bolt, Glenys Kelley and Megan Ash for providing technical assistance and advice. This work was supported in part by an Australian National Research Fellowship (ref. no. 84/305) to G. A. C.

\section{REFERENCES}

AKHURST, R. J. (1980). Morphological and functional dimorphism in Xenorhabdus spp., bacteria symbiotically associated with the insect pathogenic nematodes Neoaplectana and Heterorhabditis. Journal of General Microbiology 121, 303-309.

AKHURST, R. J. (1982). Antibiotic activity of Xenorhab$d u s$ spp., bacteria symbiotically associated with insect pathogenic nematodes of the families Heterorhabditidae and Steinernematidae. Journal of General Microbiology 128, 3061-3065.

AKHURST, R. J. (1983). Taxonomic study of Xenorhab$d u s$, a genus of bacteria symbiotically associated with insect pathogenic nematodes. International Journal of Systematic Bacteriology 33, 38-45.

AKHURST, R. J. (1986). Xenorhabdus nematophilus subsp. beddingii (Enterobacteriaceae): a new subspecies of bacteria mutualistically associated with entomophogenic nematodes. International Journal of Systematic Bacteriology 36, 454-457.

Boemare, N., Louis, C. \& Kuhl, G. (1983). Etude ultrastructurale des cristaux chez Xenorhabdus spp., bactéries inféodees aux nematodes entomophages Steinernematidae et Heterorhabditidae. Comptes rendus des séances de la société de biologie 177, 107-115.

BuRNeTtE, W. N. (1981). Western blotting electrophoretic transfer of proteins from sodium dodecyl sulphate polyacrylamide gels to unmodified nitrocellulose and radiographic detection with antibody and radio-iodinated protein A. Analytical Biochemistry 112, 195-203.

Davidson, E. W. \& Yamamoto, T. (1984). Isolation and assay of the toxic component from crystals of Bacillus thuringiensis var. israelensis. Current Microbiology 11, 171-174.

Grimont, P. A. D., Steigerwalt, A. G., Boemare, N., Hickman-Brenner, F. W., Deval, C., GriMONT, F. \& BRENNER, D. J. (1984). Deoxyribonucleic acid relatedness and phenotypic study of the genus Xenorhabdus. International Journal of Systematic Bacteriology 34, 378-388.

Hotchis , P. G. \& KAYA, H. K. (1984). Electrophoretic profiles of soluble proteins from two species of Xenorhabdus, bacteria mutualistically associated with the nematodes Steinernema spp. and Heterorhabditis spp. Journal of General Microbiology 130, 2725-2731.
Hurley, J. M., Lee, S. G., Andrews, R. E., Klowden, M. J. \& Bulla, L. A. (1985). Separation of the cytolytic and mosquitocidal proteins of Bacillus thuringiensis subsp. israelensis. Biochemical and Biophysical Research Communications 126, 961965.

Johnson, D. A., Cautsch, J. W., SPORTSMan, J. R. \& ELDER, J. H. (1984). Improved technique utilising nonfat dry milk for analysis of proteins and nucleic acids transferred to nitrocellulose. Gene Analysis Techniques 1, 3-8.

LAEMMLI, U. K. (1970). Cleavage of structural proteins during the assembly of the head of bacteriophage T4. Nature, London 227, 680-685.

Lehrbach, P. R., Jeenes, D. J. \& Broda, P. (1983). Characterisation by molecular cloning of insertion mutants in TOL catabolic functions. Plasmid 9, 112125.

Maniatis, T., Fritsch, E. F. \& Sambrook, J. (1982). Molecular Cloning: a Laboratory Manual. Cold Spring Harbor, NY: Cold Spring Harbor Laboratory.

Pfannenstiel, M. A., Ross, E. J., Kramer, V. C. \& NiCKERSON, K. W. (1984). Toxicity and composition of protease inhibited Bacillus thuringiensis var. israelensis crystals. FEMS Microbiology Letters 21, $39-42$.

PoINAR, G. O. \& Thomas, G. M. (1966). Significance of Achromobacter nematophilus Poinar \& Thomas (Achromobacteriaceae: Eubacteriales) in the development of the nematode, DD136 (Neoaplectana sp. Steinernematidae). Parasitology 56, 385-390.

Thomas, G. M. \& Poinar, G. O. (1979). Xenorhabdus gen. nov., a genus of entomopathogenic, nematophilic bacteria of the family Enterobacteriaceae. International Journal of Systematic Bacteriology 29, 352360.

Thomas, W. E. \& EllaR, D. J. (1983). Bacillus thuringiensis var. israelensis crystal $\delta$-endotoxin: effects on insect and mammalian cells in vitro and in vivo. Journal of Cell Science 60, 181-197.

Towbin, H., Staehelin, T., Gordon, J. \& Weidehi, H. (1980). A procedure for transferring proteins from polyacrylamide gels to nitrocellulose sheets and their immunological detection. Experientia 36, 734. 